UK and Japan sign agreement on \section{anti-cancer drugs}

\section{Tokyo}

UNDER a series of technology-transfer agreements, the latest of which was announced on Monday, the Japanese trading giant Sumitomo Corporation has opened a channel of access for Japanese companies to nearly all anti-cancer drug technology under development in the United Kingdom.

The latest agreement between Sumitomo and the commercial arm of the Imperial Cancer Research Fund (ICRF), a charity and Britain's largest cancer research organization, gives the Japanese company the exclusive right to act as agent in Japan for licensing drugs and inventions arising out of ICRF-funded research. Sumitomo is also able to arrange for Japanese companies to carry out development and clinical trials of ICRF-developed drug technology.

Similar agreements were signed last year with Britain's Cancer Research Campaign (CRC), another charity that funds much of Britain's cancer research, and the Medical Research Council (MRC) (See Nature 335, 487; 1988).

The agreements with CRC and ICRF give Sumitomo access to about four-fifths of Britain's cancer research, according to Jonathan Gee, marketing director of Imperial Cancer Research Technology (ICRT), the commercial subsidiary of ICRF which signed the new agreement on Monday.

At present ICRF gets only about one per cent of its income from drug technology licenses and royalties. Most of the charity's research funds come from donations, legacies and income from about 300 charity shops dotted around Britain. But in the near future, Gee expects income from intellectual-property rights to increase substantially. As an example, he points to two ICRF-developed drugs close to commercialization in the United States which are expected to make multi-milliondollar profits - ICRF 1987, a drug which reduces the side-effects of the anti-cancer drug adriamicin, and an antibodydelivered immunotoxin for treatment of graft-host rejection that will be marketed by Xoma Corporation.

But although ICRF has links with about 300 companies worldwide, only about 10 are Japanese, hence the agreement with Sumitomo. Takao Hirose of Sumitomo Corporation says that some contracts with Japanese companies and MRC - the first UK organization to sign up with Sumitomo - have already been entered into and "several companies" are examining CRC drug technology. And he is confident that there will be similar interest in ICRF technology.

David Swinbanks

NIH guidance is rejected

\section{Washington}

THE US National Institutes of Health (NIH) may already be regretting that they last week hosted a two-day meeting on conflict of interest in biomedical research backed with a promise that they would deliver a new set of guidelines within months. Far from welcoming NIH help, the overwhelming message from the several hundred conference participants was that institutions want to be left alone to tackle the issue themselves.

Diane Zuckerman, a staff member of the congressional subcommittee on human resources and intergovernmental relations, described some of the views expressed at the conference as "very discouraging" and said that Congress may introduce legislation, given that the universities appear to be unwilling to tighten up their policies. Congressional interest in the conflicts that can arise when researchers are in a position to profit financially from their research work is already high, with a subcommittee hearing on the subject held just two weeks ago (see Nature 339, 568; 22 June 1989).

No consensus on conflict of interest exists in the universities. Few universities allow faculty to hold equity in a company that finances any of their research. Those that do set varying limits on how much equity can be held. State law in New Jersey prevents faculty at Rutgers University from holding more than one per cent in equity in any company with which it has financial links. A delegate from Rutgers complained that this diminishes the entrepeneurial spirit of the faculty.

California state law requires University of California (UC) faculty to declare on their grant applications any stock holdings greater than $\$ 1,000$ in companies sponsoring their research. There is no upper limit on holdings, but a university committee reviews such applications for conflict of interest. The same review process is set in motion if a member of faculty holds a management position with a sponsor, or has received from it more than $\$ 250$ for consulting work or as a loan, or more than $\$ 50$ as a gift. In seven years almost 30,000 proposals have been examined and only seven have been rejected, although many have been modified before approval.

The process is "extremely burdensome" says Belle Cole, director of research and public policy at UC Berkeley, and costs about $\$ 500,000$ a year. But a delegate from UC San Francisco argued that "we prefer to do it within than have it done to us from outside".

The meeting tended to support the view that holding equity in a sponsor was unacceptable, not because it necessarily created a conflict of interest which could bias research results but because of the public perception that it could. This led to questions on whether restrictions should also apply to family of faculty, and whether holding equity in sponsors' competitors should also be prohibited.

Suggested ways of avoiding the appearance of a conflict of interest included giving responsibility for distribution of the funds from a sponsor to a third party, or placing between a university and a startup company a third agency to act as a 'buffer' as Johns Hopkins University has done to distance itself from the commercial applications of research. The rule at Johns Hopkins is that the university cannot invest in start-up companies. "We think it's a good rule, but we're still searching for the principle that underlies it", said David Blake, associate dean for administration and planning.

It was agreed that consultancies, gifts and loans were more acceptable, but there were wide differences of opinion over what restrictions there should be. Clinical trials on drugs or treatments were considered by some to require more stringent controls.

In the past the integrity of researchers, the research design and the disclosure of funding sources have allayed concerns about conflicts of interest. But now, researchers in a multi-centre study sponsored by the NIH on the treatment of patients after by-pass surgery have agreed to observe strict guidelines. They and their relatives will not be able to hold stock in companies distributing treatments under study until the results are made public. Paid consulting for the companies is banned. The researchers say similar guidelines should also apply to members of data- and safety-monitoring boards who have access to confidential data.

Clinical trials are already regulated by institutional review boards and often by the Food and Drug Administration and it was argued that no more regulations are necessary. But Bernadine Healy, chairman of the steering committee for the trials, said that guidelines were needed and should be developed nationally for different research projects to provide some uniformity over the academic community. This view was not widely shared.

The question now is what NIH and Congress will do. Researchers at the meeting accused Congress of sending confusing messages to the academic community. Politicians are insisting on closer relationships between federally funded researchers and private industry. But at the same time they are demanding assurances that research remains untainted by the desire for a quick profit and that federal funds are not being used to make researchers rich.

Christine McGourty 